points of maximum absorption, or most persistent edges in each of the bands measured by Hartley and Dobbie. This is shown in the following statement quoted from his paper (Wilhelm Friederichs, Zeit. für wissenschaftliche Photographie, B. iii., I54-I64, I905).

I have added in italics the wave-length numbers corresponding to Baly and Collie's oscillation frequencies for comparison :-

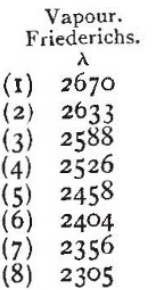

Solution in alcohnl.

Hartley and Dobbie. Difference. Baly and Collie.

$\begin{array}{ccc} & \lambda & \\ \ldots & 268 \mathrm{I} & \ldots \\ \ldots & - & \ldots \\ \ldots & 2599 & \ldots \\ \ldots & 254 \mathrm{I} & \ldots \\ \ldots & 2485 & \ldots \\ \ldots & 2429 & . . \\ \ldots & 2376 & \ldots \\ \ldots & 2330 & \ldots\end{array}$

\begin{tabular}{l} 
II \\
\hline II \\
15 \\
27 \\
25 \\
20 \\
25
\end{tabular}

$\begin{array}{cc}\lambda \\ \ldots & 2683 \\ \ldots & 2656 \\ \ldots . & 2610 \\ \ldots & 2554 \\ \ldots & 2484 \\ \ldots & 2433 \\ \ldots & 2380 \\ \ldots & -\end{array}$

He points out that the bands of the substance in solution which without doubt correspond with those of the vapour are all shifted towards the red, as might be expected, but that the shift appears to be greater the smaller the wave-lengths of the absorbed rays. The comparison of Baly and Collie's numbers with those of Hartley and Dobbie is very interesting in this connection, inasmuch as they show a close general agreement in their divergence from the measurements of Friederichs. Furthermore, the following points may be noted :-

First, the omission of the second band in Hartley and Dobbie's spectrum; second, the omission of the eighth band by Baly and Collie; third, there is a close agreement between Hartley and Dobbie's and Baly and Collie's numbers in the first, fifth, sixth, and seventh bands, but the two sets of measurements for the third and fourth bands differ more widely than the others.

It may be mentioned that the second very narrow band is visible on the photographs taken by Hartley and Dobbie, though it can scarcely be considered as measurable; no doubt a longer exposure would have rendered it more plainly. Those who have measured similar series of bands in the visible region, for example, those in the spectrum of potassium permanganate, which are also eight in number, will appreciate the close approximation of the above figures.

Royal College of Science, Dublin, September 19.

\section{Rhymes on the Value of $\pi$.}

Trie following rhyme is in imitation of the French and German verses given in NATuRE (August I7) in which the number of letters in each word correspond to a numeral in the value of $\pi$. The three concluding lines are somewhat obscure; it seems to have occurred to the author that the method is a misuse of language, and he expresses the hope that NATURE will take a more lenient view than Dr. Johnson might be imagined to express.

To the Editor of NATURE.

Sir,--I send a rhyme excelling

$$
\begin{array}{lllllll}
3 & \text { I } & 4 & \text { I } & 5 & 9
\end{array}
$$

In sacred truth and rigid spelling.

Numerical sprites elucidate

$$
\begin{array}{lll}
9 & 7 & 9
\end{array}
$$

For me the lexicon's dull weight.

$$
\begin{aligned}
& \begin{array}{lccccc}
3 & 2 & 3 & 8 & 4 & 6 \\
& \text { If } & & \\
& &
\end{array} \\
& \text { Not you complain, } \\
& 338
\end{aligned}
$$

Tho' Dr. Johnson fulminate.

$$
\begin{array}{llll}
3 & 2 & 7 & 9
\end{array}
$$

NO. I 875, VOI. 727
The Celtic Pony.

IN a review, signed "R. L.," of "The Færöes and Iceland," in NATURE of September 2I (p. 506), I was surprised to read that I had credited Prof. Ewart "with being the first to regard Przewalsky's horse as a variety of Equus caballus." I have just re-read the paragraph relating to the wild horse in my "Appendix on the Celtic Pony," and I can find no passage which, it seems to me, could by any possibility be made to bear this strange construction.

Sanson's subspecies $E, c$. hibernicus appears to include all the various ponies of the British Isles, the Breton in France, as well as the horses of Iceland, Norway, and Sweden. It has been recognised for some time past that the Icelandic horses are of two different types, while the Swedish horses are admittedly very mixed. Moreover, as a result of a recent tour in Norway, it has become evident to me that there are in that country at least two distinct kinds of native horses (represented by the pure fjord horse and the Gudbrandsdal horse). In view of these considerations, the statement that the Celtic pony is "probably inseparable "from the somewhat heterogeneous assemblage (as it now appears to be) included under $E$. c. hibernicus becomes a little obscure. But, as "R. L." points out, I did not make this statement. I grant, however, that it might have been better had I made some allusion to this matter.

But why $I$ should have been expected in an "Appendix on the Celtic Pony" to have entered into a discussion as to the proper technical name to apply to $E$. przewalskyi or to have recorded an irrelevant criticism of Prof. Ridgeway's new name of $E$. $c$. libycus, I am at a loss to understand.

Francis H. A. Marshall.

The University, Edinburgh, September 24.

\section{GREEK ARCHAOLOGY.'}

THE archæologist justly ranks himself as a contributor to the world's knowledge on the same level as those who discover previously unknown forces in nature or new facts in the life-history of animals, extinct or living. Archæology, which is a branch of the great science of anthropology, discovers and correlates new facts in the early history of civilisation. Greek archæological discovery must always be of most especial interest, since it tells us of the origins of that early civilisation of the Mediterranean basin from which our present-day culture is derived. One of the most welcome yearly publications dealing with the subject is the "Annual of the British School at Athens," the tenth volume of which lies before us. It deals with the British work of I903-4, besides containing independent articles on matters of archæological interest.

Dr. Arthur Evans's work at Knossos does not occupy so much space in the "Annual" as usual. The discoveries of the year, while most interesting, were not so new and epoch-making as those of former years, and the chief find, the tombs of "Ja'fàr's Papoúra " ( described by Dr. Evans in a separate communication to Archaeologia. The first-named tombs, on a hill north of the Knossian palace, were of various types; (I) chamber-tombs approached by a dromos; " in many cases these contained clay coffins, in which the dead had been deposited in cists, their knees drawn towards the chin"; (2) shaft-graves; (3) pit-caves, " or pits giving access to a walled cavity in the side below." In 2 and 3 the skeletons were extended at full length. On the hill of Isópata, about two miles north of Ja'fàr's Papoúra, a very fine tomb, no doubt that of a king, was found, with a smaller one by its side. The larger consisted of a square chamber of limestone blocks, eight metres by six, "with the 1 "The Annual of the British School at Athens," No. x. Session xgo3-4. (Loncon: Macmillan and Co., Ltd.) 